\title{
Fiddler crab control of cordgrass primary production in sandy sediments
}

\author{
Christine Holdredge*, Mark D. Bertness, Nicholas C. Herrmann, Keryn B. Gedan \\ Department of Ecology and Evolutionary Biology, Brown University, Providence, Rhode Island 02912, USA
}

\begin{abstract}
The cordgrass Spartina alterniflora Loisel is a foundation species critical to the establishment and maintenance of western Atlantic salt marshes. Although the factors regulating cordgrass growth along sheltered, fine-sediment shorelines have been exhaustively studied, less is known about the mechanisms that maintain cordgrass production in high-energy marshes characterized by sandy substrates. We investigated whether deposit-feeding fiddler crabs Uca pugilator Bosc and $U$. pugnax Smith can mediate local physical conditions and nutrient availability and stimulate cordgrass primary production on sandy marsh sediments. We experimentally removed fiddler crabs from $3 \times$ $3 \mathrm{~m}$ plots in an exposed, sandy marsh in Wellfleet, Massachusetts, USA, and found that above- and belowground cordgrass biomass decreased by $>53 \%$ and $50 \%$, respectively, and above- and belowground nitrogen in cordgrass $\left(\mathrm{g} \mathrm{N} \mathrm{m}^{-2}\right)$ decreased by $>47 \%$ and $45 \%$ in fiddler crab removal plots compared to controls. Fiddler crab removal did not measurably influence sediment edaphic parameters, such as redox potential or waterlogging, suggesting that fiddler crabs enhance cordgrass productivity through nutrient deposition on sandy sediments and thus may be a critical component in the successful establishment and maintenance of salt marshes that develop along high-energy shores.
\end{abstract}

KEY WORDS: High energy marsh · Positive interactions $\cdot$ Nutrient deposition $\cdot$ Nutrient limitation · Spartina alterniflora $\cdot$ Uca pugilator $\cdot$ Uca pugnax

\section{INTRODUCTION}

Along temperate coastlines, salt marsh ecosystems stabilize coastal sediments and buffer against shoreline erosion (Frey \& Basan 1985). In the western Atlantic, the growth and productivity of the foundation species Spartina alterniflora Loisel (hereafter, cordgrass) largely determine how effectively marsh ecosystems perform these functions. Cordgrass colonizes exposed shores and facilitates the establishment of infaunal invertebrate and microbial communities by alleviating predation (Bell et al. 1978) and harsh physical conditions, e.g. desiccation and wave stress (Chapman 1960, Bortolus et al. 2002). Cordgrass stems and roots also capture and bind sediments to form peat and drive the vertical accretion of the marsh platform (Redfield \& Rubin 1962, Redfield 1972), a process that alleviates inundation stress, alters sediment dynamics, and enhances nutrient retention (Osgood \& Zieman 1993, Craft et al. 1999) to promote the succession of high marsh plants. Despite the importance of cordgrass in shoreline stabilization and marsh development, few studies have investigated the mechanisms that regulate its productivity in high-energy environments.

Physical factors that are largely determined by geological and hydrological forces, such as salinity, drainage, and nutrient availability, have long been thought to control the primary production of cordgrass (Teal 1962, Odum 1969, Mendelssohn \& Morris 2000). On wave-protected shores where most marsh studies have been performed, for example, cordgrass growth is regulated by low oxygen concentrations and nutrient availability in fine-grained, organic marsh sediments. Biological interactions, however, can mediate local physical conditions and primary production in coastal marine environments. Specifically, burrowing, feed- 
ing, and excreting activities of benthic filter feeders (i.e. mussels and sponges; Bertness 1984, Ellison et al. 1996, Peterson \& Heck 1999) and deposit feeders (i.e. crabs; Bertness 1985, Botto \& Iribarne 2000) have been shown to alter substrate chemistry, drainage, and nutrient availability and indirectly mediate the growth of halophytic plants.

Crabs are recognized commonly as ecosystem engineers in coastal marine habitats because of their feeding and burrowing effects on substrate conditions (e.g. Montague 1980, Jones et al. 1994, Bortolus \& Iribarne 1999). The burrowing of sesarmid and fiddler crabs in mangrove forests modifies soil organic content, nutrient availability, drainage, and redox conditions to influence sediment topography and biochemistry (reviewed by Kristensen 2008). In Argentinean salt marshes, burrows formed by grapsid crabs aerate anoxic soils, which triggers mycorrhizal infection of plant roots and stimulates primary production (Daleo et al. 2007). These burrows also concentrate excretory waste and organic debris to mediate nutrient cycling (Botto et al. 2005, Fanjul et al. 2007). In New England (USA), mud fiddler crabs Uca pugnax Smith significantly increase drainage, oxidation-reduction potential, and decomposition of belowground plant debris to regulate soil conditions and promote cordgrass production (Bertness 1985).

The impact of crabs on cordgrass growth in highenergy, sandy marshes that are prevalent throughout temperate barrier islands and exposed headlands has not been explored. Sand Uca pugilator Bosc and mud fiddler crabs dominate the infaunal community on sandy shores on the east coast of the USA (Teal 1958, Montague 1980). On Cape Cod, Massachusetts, USA, fiddler crab burrow densities in sandy cordgrass habitats are high, ranging from 30 to 175 burrows $\mathrm{m}^{-2}$ with individual burrows typically penetrating 5 to $25 \mathrm{~cm}$ (C. Holdredge \& N. Herrmann unpubl. data). In low-oxygen, muddy sediments, fiddler crabs actively aerate soils and reduce waterlogging by excavating burrows and reduce meiofaunal abundance by sifting through surface sediments for organic debris (Bell et al. 1978, Mendelssohn \& Seneca 1980, Hoffman et al. 1984, Bertness 1985). In porous, inorganic sandy soils along exposed shorelines, however, these effects may not be of consequence to cordgrass growth, and crabs may impact substrates and primary production through other mechanisms. In particular, fiddler crabmediated deposition of nutrients may be more critical to cordgrass growth and production since sandy marsh soils are generally nitrogen-limited due to poor nutrient retention (Craft et al. 1991, Osgood \& Zieman 1993, Tyler et al. 2003). As deposit feeders, fiddler crabs consume diatoms, algae, and nitrogen-fixing cyanobacteria and excrete waste rich in ammonium- based compounds, actively redistributing nutrients from the flats where they feed to vegetated areas where they tend to burrow (Montague 1980, Regnault 1987).

We examined the hypothesis that fiddler crabs regulate cordgrass primary production in sandy New England marsh habitats with a crab removal experiment. Our findings suggest that fiddler crabs can control cordgrass productivity on sandy substrates by mediating nitrogen available for plant uptake and indicate that crabs may perform a critical role in the persistence of salt marshes along exposed, sandy coastlines.

\section{MATERIALS AND METHODS}

Study site. Our study was performed at the Great Island marsh in Wellfleet, Massachusetts $\left(41^{\circ} 55^{\prime}\right.$ $\left.37.86^{\prime \prime} \mathrm{N}, 70^{\circ} 4^{\prime} 16.48^{\prime \prime} \mathrm{W}\right)$. The site is characterized by a $\sim 100 \mathrm{~m}$ wide, monospecific band of cordgrass in the daily flooded low marsh and a Spartina patens Muhldominated high marsh. Winter storms annually scour the low marsh vegetation in spring, leaving very little plant detritus in the marsh, and maintain extensive sand over-wash areas. The sand fiddler crab is the numerically dominant crab on sandy substrates at the site. Other common crabs at the site include the mud fiddler crab and the herbivorous marsh crab Sesarma reticulatum, which is most abundant on peat substrates and only sparsely distributed in sand (Bertness et al. 2009). Where we performed our studies, the substrate was composed predominately of large sand particles ( $>80 \%$ by dry weight $>0.6 \mathrm{~mm}$ ) and characterized by low organic content $(<1.5 \%$ dry weight, C. Holdredge unpubl. data).

Crab removal. We initiated a crab removal experiment at Great Island on 8 May 2008 to test the hypothesis that fiddler crabs can regulate cordgrass growth in sandy marsh substrates. Along a $100 \mathrm{~m}$ stretch of the marsh, we demarcated 21 plots $(3 \times 3 \mathrm{~m})$ in the sandy cordgrass zone, minimizing initial plot differences in elevation, substrate composition, and cordgrass stem density, and assigned each plot 1 of 3 experimental treatments: (1) crab removal cage, (2) removal (procedural) control cage, and (3) crab access.

To deplete fiddler crab densities, we constructed $3 \times$ $3 \times 1 \mathrm{~m}$ (length $\times$ width $\times$ height) open-top cages of galvanized hardware cloth ( $7 \mathrm{~mm}$ mesh size). Cages were inserted $15 \mathrm{~cm}$ into the marsh $(\mathrm{n}=7$ replicates per treatment) to prevent crabs from burrowing into the cages and a $20 \mathrm{~cm}$ wide strip of aluminum flashing was bent in half and stapled over the top edge of cages to inhibit crabs from climbing in. For removal controls, we installed cages with the same aluminum flashing barrier and dimensions as the crab removal cages but 
elevated them $5 \mathrm{~cm}$ above the marsh surface to allow passive migration of crabs. When necessary, we removed any wrack that accrued on caging mesh to avoid changes in water flow or retention around crab removal and removal control cages. Crab access plots were left unmanipulated. We walked around the perimeter of removal control and crab access plots to standardize disturbance effects. All data were taken $>50 \mathrm{~cm}$ from the edge of experimental plots to minimize edge effects on substrate, crab, and cordgrass parameters.

We installed a $7.5 \times 20 \mathrm{~cm}$ (diameter $\times$ depth) pitfall trap (see Bertness et al. 2009) in each corner of the removal cages to passively reduce crab densities for the duration of the experiment. Traps were emptied at least twice a week. We also handpicked crabs to supplement trapping. At each cage, we spent 10 minutes picking crabs off the marsh surface to standardize manual reduction effort and picked crabs twice a week for Weeks 1 to 4 and once a week for the remainder of the experiment. All captured crabs were identified to species, counted, and released $>25 \mathrm{~m}$ from experimental plots. On 5 August 2008, we assessed the effectiveness of the crab removal treatments by counting the number of $U_{C a}$ on the marsh surface and surveying UCa spp. burrow densities and diameters (10 burrows quadrat ${ }^{-1}$ ) in $30 \times 30 \mathrm{~cm}$ quadrats randomly positioned in each plot (Bertness 1985, Nobbs \& McGuiness 1999). We then measured the carapace width of 10 random crabs sampled from each plot to estimate the relative distribution of adult and juvenile crabs and used the carapace width, $X$, to calculate the mean biomass of $U_{C a}, Y$, where $\log Y=3.1090(\log X)+0.8154$ (Colby \& Fonseca 1984). Total crab biomass was then estimated for each plot using crab density and biomass values.

In early August, we inspected all plots for a redox boundary layer by inserting a knife $25 \mathrm{~cm}$ into the substrate and gently pushing apart the substrate to view a depth profile. No visible redox boundary layer was evident in any plot and the lack of sheet flow during incoming and outgoing tides suggested that the sandy substrate at this site was porous and had high percolation rates. We quantified relative soil oxygen availability by measuring the redox potential $\left(\mathrm{E}_{\mathrm{H}}\right)$ at surface $(2 \mathrm{~cm})$ and subsurface $(5 \mathrm{~cm})$ depths in each plot (see Howes et al. 1981 for methods). Two hours after high tide, we collected 6 sediment cores $(3 \times 5 \mathrm{~cm}$, diameter $\times$ depth) from random locations within each plot to assess water saturation as a proxy for drainage efficiency (3 cores) and sediment nitrogen concentration (3 cores). Water saturation cores were weighed wet in the field, oven-dried at $60^{\circ} \mathrm{C}$ for $72 \mathrm{~h}$, and reweighed $(\%$ saturation $=[\mathrm{g}$ wet soil $-\mathrm{g}$ dry soil $] / g$ wet soil $)$. Sediment nitrogen cores were sieved, and nitrate $\left(\mathrm{NO}_{3}{ }^{-}\right)$ and ammonium $\left(\mathrm{NH}_{4}{ }^{+}\right)$were extracted with $2 \mathrm{M}$ potas- sium chloride. Nitrate and ammonium concentrations were analyzed with a QuikChem QC8500 Automated Ion Analyzer (Lachat Instruments, Hach Company) using standard colorimetric methods. We collected sediment samples in late July to assess the nutrient concentrations while cordgrass was still growing. Water saturation, nitrate, and ammonium data were pooled and averaged across plots for statistical analysis.

To estimate the relative supply of nitrogen available to plants, we measured the accumulation of nitrogen in leaf, root, and rhizome structures in mid-August. Since cordgrass growth is known to be nitrogen-limited in New England marshes (Valiela \& Teal 1974, Levine et al. 1998) and responds positively to fertilization at our study site (C. Holdredge \& M. Bertness unpubl. data), the total uptake of nitrogen provides an integrated measure of the supply of nitrogen available for plant growth over the duration of the experiment (Bertness et al. 2002, Tyler et al. 2003). To estimate total nitrogen uptake, we clipped, pooled, and powdered $1 \mathrm{~cm}$ sections of 20 random cordgrass leaves, roots, and rhizomes harvested from each plot and processed samples through an NC2100 Elemental Analyzer (CE Instruments), which calculates $\% \mathrm{C}$ and $\% \mathrm{~N}$ content of organic tissue (see Supplement 1 at www. int-res.com/articles/suppl/m399p253_app.pdf for further discussion). We then calculated aboveground nitrogen uptake (leaf $\% \mathrm{~N} \times$ aboveground biomass $\left[\mathrm{g} \mathrm{m}^{-2}\right]$ ) and belowground nitrogen uptake (rhizome $\% \mathrm{~N} \times$ rhizome biomass $\left[\mathrm{g} \mathrm{m}^{-2}\right]+$ root $\% \mathrm{~N} \times$ root biomass $\left[\mathrm{g} \mathrm{m}^{-2}\right]$ ) using $\% \mathrm{~N}$ values and plant biomass (see below) for each plot.

We harvested cordgrass stems at ground level from $30 \times 30 \mathrm{~cm}$ sampling quadrats in each plot on 27 August 2008 to quantify the effect of fiddler crabs on cordgrass biomass. For each sample, we counted the number of stems, measured the length of 5 randomly chosen stems, and oven-dried and weighed the biomass of the total aboveground sample. We also measured belowground biomass by excavating all cordgrass roots and rhizomes from a $30 \times 30 \times 30 \mathrm{~cm}$ (length $\times$ width $\times$ depth) sampling block positioned randomly within each plot. Because roots and rhizomes are concentrated in the top $25 \mathrm{~cm}$ of the sediment profile (Howes et al. 1981), belowground samples were representative of total belowground biomass. Samples were rinsed over a $2 \mathrm{~mm}$ mesh sieve, separated into live root and rhizome structures, oven-dried, and weighed.

All data were log-transformed as necessary to meet the assumptions of parametric statistics and analyzed using a 1-way crab removal treatment analysis of variance (ANOVA) with differences between treatments assessed with Tukey's post hoc comparison tests. Statistical tests were performed using JMP software (SAS Institute). 
Table 1. Uca spp. Burrow parameters, carapace size, and crab density obtained from surveys conducted in August 2008, and mean crab biomass and the total crab biomass estimates. Data are mean $\pm \mathrm{SE}$; superscripts indicate the results from Tukey's post hoc analysis. See 'Materials and methods' for a description of the treatments

\begin{tabular}{|c|c|c|c|c|c|c|}
\hline Treatment & $\begin{array}{l}\text { Crab burrows } \\
\left(\text { no. } \mathrm{m}^{-2}\right)\end{array}$ & $\begin{array}{c}\text { Burrow } \\
\text { diameter }(\mathrm{mm})\end{array}$ & $\begin{array}{l}\text { Carapace } \\
\text { size (mm) }\end{array}$ & $\begin{array}{l}\text { Crab density } \\
\text { (ind. } \mathrm{m}^{-2} \text { ) }\end{array}$ & $\begin{array}{c}\text { Mean crab } \\
\text { biomass }(\mathrm{g})\end{array}$ & $\begin{array}{c}\text { Total crab } \\
\text { biomass }\left(\mathrm{g} \mathrm{m}^{-2}\right)\end{array}$ \\
\hline Crab removal & $148 \pm 6^{\mathrm{a}}$ & $9.99 \pm 0.30^{\mathrm{b}}$ & $8.43 \pm 0.49^{b}$ & $124 \pm 7^{b}$ & $5.72 \pm 0.97^{\mathrm{b}}$ & $720 \pm 141^{b}$ \\
\hline Crab access & $141 \pm 10^{\mathrm{a}}$ & $12.51 \pm 0.54^{\mathrm{a}}$ & $12.11 \pm 1.27^{\mathrm{a}}$ & $157 \pm 13^{\mathrm{a}, \mathrm{b}}$ & $20.09 \pm 5.7^{\mathrm{a}}$ & $2831 \pm 590^{\mathrm{a}}$ \\
\hline Removal control & $144 \pm 7^{a}$ & $11.69 \pm 0.59^{a, b}$ & $11.47 \pm 0.85^{\mathrm{a}, \mathrm{b}}$ & $171 \pm 9^{a}$ & $15.47 \pm 3.25^{\mathrm{a}, \mathrm{b}}$ & $2745 \pm 622^{\mathrm{a}}$ \\
\hline
\end{tabular}

Table 2. Statistical summary of substrate parameters collected in August 2008 in fiddler crab removal treatments. $\mathrm{E}_{\mathrm{H}}$ refers to redox potential measured in $\mathrm{mV}, \%$ saturation refers to water weight/total sediment sample weight, and nitrate and ammonium concentrations are measured in $\mu \mathrm{g} \mathrm{g}^{-1}$ dry soil. Data are mean \pm 1 $\mathrm{SE}$; superscripts indicate results from Tukey's post hoc comparison test. See 'Materials and methods' for a description of the treatments

\begin{tabular}{|lccccc|}
\hline Treatment & $\mathrm{E}_{\mathrm{H}} 2 \mathrm{~cm}$ & $\mathrm{E}_{\mathrm{H}} 5 \mathrm{~cm}$ & $\%$ saturation & {$\left[\mathrm{NO}_{3}{ }^{-}\right]$} & {$\left[\mathrm{NH}_{4}{ }^{+}\right]$} \\
\hline $\begin{array}{l}\text { Crab } \\
\text { removal }\end{array}$ & $8.7 \pm 5.7^{\mathrm{a}}$ & $3.0 \pm 5.3^{\mathrm{a}}$ & $17.9 \pm 0.7^{\mathrm{a}}$ & $0.46 \pm 0.08^{\mathrm{a}}$ & $1.17 \pm 0.07^{\mathrm{a}}$ \\
$\begin{array}{l}\text { Crab } \\
\text { access }\end{array}$ & $23.3 \pm 9.5^{\mathrm{a}}$ & $7.8 \pm 6.2^{\mathrm{a}}$ & $19.6 \pm 0.6^{\mathrm{a}}$ & $0.28 \pm 0.06^{\mathrm{a}}$ & $1.26 \pm 0.05^{\mathrm{a}}$ \\
$\begin{array}{l}\text { Removal } \\
\text { control }\end{array}$ & $14.5 \pm 3.0^{\mathrm{a}}$ & $5.3 \pm 6.7^{\mathrm{a}}$ & $19.1 \pm 0.5^{\mathrm{a}}$ & $0.32 \pm 0.06^{\mathrm{a}}$ & $1.36 \pm 0.08^{\mathrm{a}}$ \\
\hline
\end{tabular}

\section{RESULTS}

In May, June, July, and August, we handpicked an average monthly sum of $107,147,82$, and 45 crabs, respectively, from each removal cage for a cumulative average of 381 crabs removed per cage over the duration of the experiment. Although burrow densities were similar across treatments $\left(F_{2,18}=0.22, \mathrm{p}=0.8012\right)$, burrow diameters were narrower $\left(F_{2,18}=6.83\right.$, $\mathrm{p}=0.0062$ ) and the carapace width of crabs caught were smaller $\left(F_{2,18}=4.51\right.$, $\mathrm{p}=0.0259)$ in removal cages compared to crab access treatments

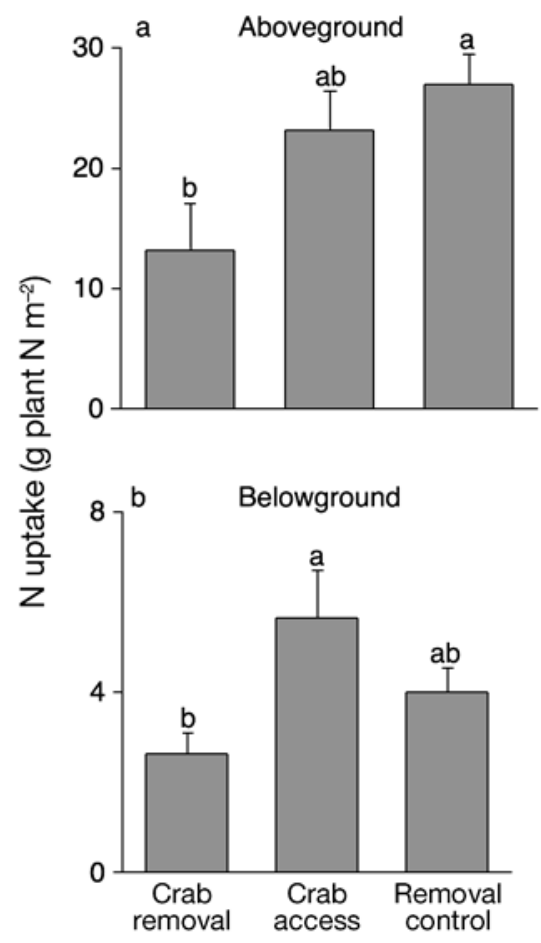

Fig. 1. Spartina alterniflora. Total uptake of nitrogen by cordgrass in (a) aboveground leaf and (b) belowground root and rhizome structures as a function of the crab removal treatment. Data are mean $\pm 1 \mathrm{SE}$ for 7 replicates per treatment
(Table 1). In removal controls, burrow density and crab carapace width values were also greater than in crab removal treatments, but the difference was not statistically significant. The total biomass of fiddler crabs, the most integrative measure of crab abundance, was nearly 4 times higher in both crab access and removal control cages than in removal cages $\left(F_{2,18}=5.67, \mathrm{p}=\right.$ 0.0123 , Table 1). Overall, we found that adult crabs were substantially depleted in removal cages, and the majority of crabs extracted were recruits and juveniles.

Redox potential $\left(\mathrm{E}_{\mathrm{H}}\right)$ values were positive and consistent across all plots, suggesting that sandy soils were generally oxygenated and crab removal did not influence $E_{H}$ at either surface $\left(F_{2,18}=1.24, p=0.3186\right)$ or subsurface depths $\left(F_{2,18}=0.16, \mathrm{p}=0.8569\right.$, Table 2$)$. Similarly, we found no effect of crab removal on water saturation $\left(F_{2,18}=2.06, \mathrm{p}=0.1563\right)$ or sediment nitrate $\left(F_{2,18}=2.26, \mathrm{p}=0.1335\right)$ and ammonium $\left(F_{2,18}=1.50\right.$, $\mathrm{p}=0.2492$ ) concentrations (Table 2).

In crab access and removal control treatments, however, plants took up an average of 75 and $104 \%$, respectively, more nitrogen in aboveground structures $\left(F_{2,18}=4.75, \mathrm{p}=0.0220\right.$, Fig. $\left.1 \mathrm{a}\right)$ and 113 and 52\%, respectively, more in belowground structures $\left(F_{2,18}=\right.$ 4.57, $\mathrm{p}=0.0248$, Fig. $1 \mathrm{~b})$ than cordgrass in crab removal cages. Cordgrass primary production also responded to the experimental reduction in crab density (Fig. 2). Aboveground, cordgrass stem density 

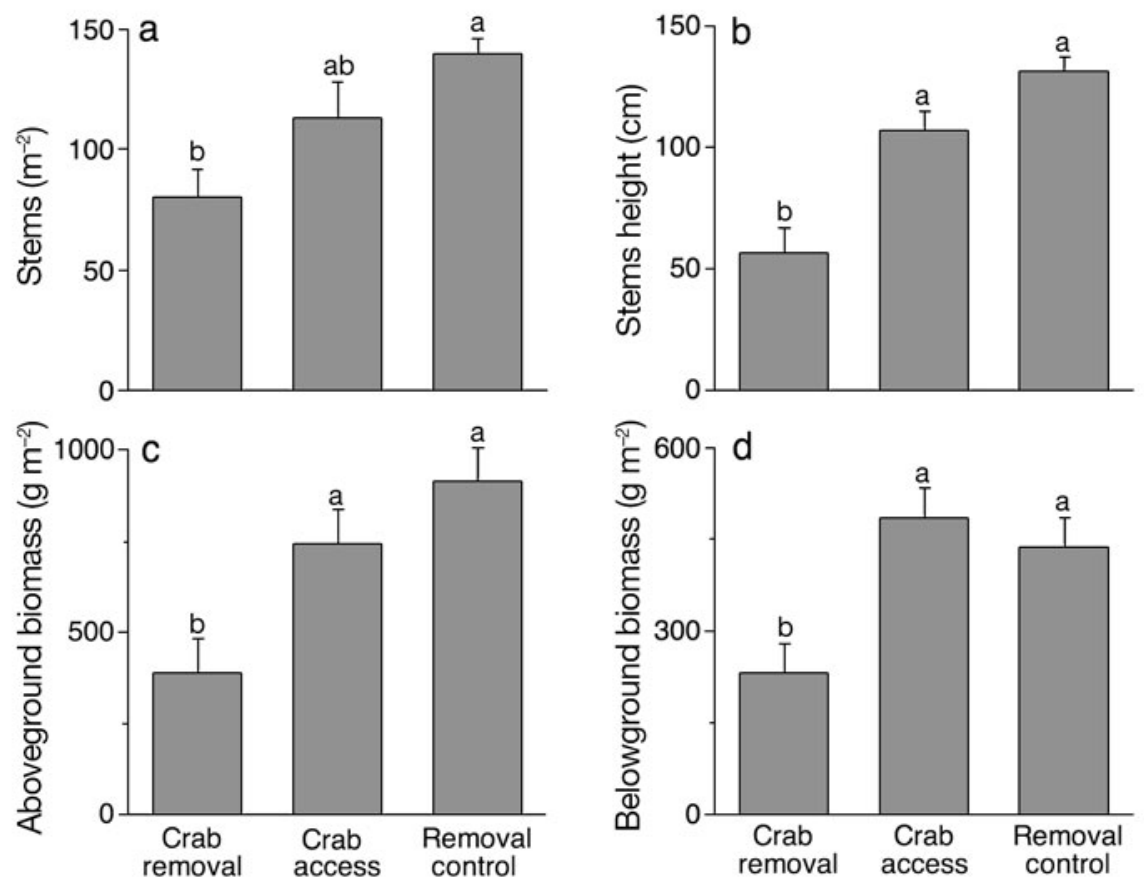

Fig. 2. Spartina alterniflora. Effect of the crab removal treatment on cordgrass growth parameters: (a) stem density, (b) stem height, (c) aboveground biomass, and (d) belowground biomass. Samples were harvested after 1 growing season; data are mean $\pm 1 \mathrm{SE}$ for 7 replicates per treatment

$\left(F_{2,18}=7.47, \mathrm{p}=0.0044\right)$, stem height $\left(F_{2,18}=10.30, \mathrm{p}=\right.$ $0.0010)$, and biomass values $\left(F_{2,18}=9.37, \mathrm{p}=0.0016\right)$ were all lowest in crab removal cages. Belowground, root $\left(F_{2,18}=3.78, \mathrm{p}=0.0425\right)$ and rhizome biomass $\left(F_{2,18}=9.94, \mathrm{p}=0.0012\right)$ also decreased substantially when adult fiddler crab densities were reduced (Fig. 2).

\section{DISCUSSION}

Our results suggest that fiddler crabs mechanistically control primary production in sandy Cape Cod salt marshes by mediating the supply of nitrogen available to cordgrass. Consequently, fiddler crabs may perform a previously unrecognized but potentially critical role in maintaining sandy salt marshes that prevail along headlands, barrier islands, and highly exposed shorelines where humans rely on these ecosystems to stabilize sediments and mitigate erosion.

\section{Crab effects on sandy marsh soils}

Previous studies investigating the effects of fiddler crabs on cordgrass have focused on fine sediment marshes along wave-protected coasts where waterlog- ging and anoxia typically inhibit cordgrass primary production. Under such conditions, fiddler crab burrowing can indirectly enhance cordgrass production by oxygenating sediments at shallow depths $(<10 \mathrm{~cm})$ where cordgrass roots and rhizomes are concentrated and by increasing drainage (Bertness 1985). Sandy marsh soils are consistently more oxygenated than finer, muddier sediments (Osgood \& Zieman 1993, Tyler \& Zieman 1999) and, in the sandy soils at our study site, crabs did not significantly influence sediment saturation (waterlogging) or oxygen availability at shallow depths (Table 2). Since fiddler crabs can burrow up to $25 \mathrm{~cm}$, they may affect sediment redox at deeper depths than we measured, so we cannot verify the insignificance of their effect with certainty. Redox values were positive across all of our experimental plots, indicating that oxygen levels were relatively high and, therefore, oxygen limitation was probably not responsible for the decrease in cordgrass biomass observed in fiddler crab removal cages.

The sandy substrate at our Cape Cod study site was characterized by low nitrate and ammonium concentrations (see Tuerk \& Aelion 2005, Pruell et al. 2006 for comparisons). Nitrogen has long been recognized as a limiting factor in temperate salt marsh aboveground primary production (e.g. Valiela \& Teal 1979), and studies comparing nutrient pools in adjacent marshes with different sediment dynamics have shown that pore water and sediment nitrogen concentrations are even lower in sandy soils than in older, peat-based sediments (Craft et al. 1991, Osgood \& Zieman 1993, Tyler et al. 2003, K. Gedan unpubl. data for New England marshes). This trend and our results are likely driven by the inability of sandy soils to accumulate nutrient reservoirs because nitrogen leaches rapidly through large-grained, inorganic substrates (Osgood \& Zieman 1993, Thompson et al. 1995, Craft 1996). Consequently, the persistent deposition of nitrogen by crabs throughout the growing season is likely critical to the production of cordgrass in sandy systems. In high-energy, exposed marshes where sandy sediments are a permanent feature, we predict that this biotic source of nutrients is essential to maintaining vegetation over prolonged periods. In young and constructed salt marshes where sandy sediments are also common (Osgood \& Zieman 1993, Craft et al. 1999, Tyler et al. 2003), however, nutrient deposition by infaunal organ- 
isms may be critical during their development, but becomes less important as substrates mature and nutrient pools accumulate.

\section{Crab effects on cordgrass biomass on sandy soils}

Although we did not detect differences in soil nitrogen concentrations, the amount of nitrogen taken up by cordgrass did vary across our experimental plots (Fig. 1). Where fiddler crabs were removed, cordgrass took up less nitrogen in above- and belowground structures compared to adjacent crab access and removal control areas with natural densities of fiddler crabs. There was considerable variation in nitrogen uptake within treatments, however, and the patterns in nitrogen accumulation across treatments differed for above- and belowground structures. Since we subsampled leaves, roots, and rhizomes from $30 \times 30 \mathrm{~cm}$ areas rather than from the entire $3 \times 3 \mathrm{~m}$ plot, both within and among plot variation likely affected our response values and ability to detect consistent patterns in nitrogen uptake across crab removal treatments. Despite the variability in response of aboveand belowground structures, our trends in nitrogen accumulation suggest that fiddler crabs, especially the larger, adult crabs that were effectively removed from cages, can locally increase the availability of nitrogen to plants likely though the excretion of ammonium-rich wastes (Montague 1980). The close proximity of fiddler crab burrows to cordgrass roots and rhizomes and high ambient density of fiddler crabs further suggest that the potential for plant absorption of excreted nitrogenbased compounds is high.

Cordgrass growing in crab access and removal control treatments was nearly twice as productive as cordgrass in cages (Fig. 2). Aboveground, we recorded significant reductions in cordgrass stem density, stem height, and overall biomass in crab removal cages after only 4 mo. Previous research has demonstrated that cordgrass biomass and stem density are negatively correlated with sediment erosion and positively correlated with sediment capture (reviewed by FitzGerald et al. 2008). Thus, we predict that by stimulating cordgrass growth, fiddler crabs may minimize erosion and enhance the capture of sediment in nutrient-depleted marshes. Belowground, both root and rhizome biomass also decreased in crab removal treatments, a response that would likely decrease the rate of sedimentbinding processes necessary for peat development and marsh accretion. Because peat development and vertical accretion of the marsh platform are dependent on the capture and binding of sediment (Redfield \& Rubin 1962), the concurrent reduction in above- and belowground biomass may have important negative feed- backs on the development and maintenance of coastal marsh habitats over longer time scales than evaluated in this study.

\section{Conservation implications}

Challenged by accelerating rates of sea level rise, our ability to facilitate the development of new marshes and protect existing ones is critically dependent on the growth and productivity of the salt marsh foundation species Spartina alterniflora, which builds peat and drives the vertical accretion of these biogenic systems (Mendelssohn \& Morris 2000, Morris et al. 2002). Years of research have exposed the physical and biological factors controlling cordgrass growth in marshes along wave-protected shores, yet our knowledge of the mechanisms regulating growth in sandy, nutrient-depleted soils characteristic of high-energy environments and young or constructed salt marshes is limited.

Our results suggest that the paucity of nitrogen is probably the most important factor influencing the growth of Spartina alterniflora in marshes with sandy substrates. To date, much of the research investigating nitrogen cycles in salt marshes has focused on terrestrial and anthropogenic inputs, and the contribution of the biotic community has often been overlooked (but see Tyler et al. 2003, Botto et al. 2005, Fanjul et al. 2008). The present study demonstrates that infaunal fiddler crabs can stimulate cordgrass growth through the deposition of nitrogen-rich compounds and may be an essential component in the persistence of salt marshes found along wave-exposed shores.

These results predict that infaunal communities perform a previously underappreciated role in mediating the interactions between relative sea level, edaphic sediment conditions, and plant growth in coastal systems. Consequently, we recommend that coastal managers assigned the task of maintaining shorelines assess and incorporate the composition and function of benthic assemblages in management plans for high energy systems, as these organisms are key players in sustaining ecosystem function.

Acknowledgements. We thank S. Smith and the Cape Cod National Seashore and National Park Service for facilitating experimental work, and M. K. Lane and A. Altieri for assistance in the field. This study was supported by the Rhode Island Sea Grant and National Science Foundation Ecology Program.

\section{LITERATURE CITED}

Bell SS, Watzin MC, Coull BC (1978) Biogenic structure and its effect on the spatial heterogeneity of meiofauna in a salt marsh. J Exp Mar Biol Ecol 35:99-107 
Bertness MD (1984) Ribbed mussels and Spartina alterniflora production in a New England salt marsh. Ecology 65: 1794-1807

Bertness MD (1985) Fiddler crab regulation of Spartina alterniflora production on a New England salt marsh. Ecology 66:1042-1055

- Bertness MD, Ewanchuk PJ, Silliman BR (2002) Anthropogenic modification of New England salt marsh landscapes. Proc Natl Acad Sci USA 99:1395-1398

Bertness MD, Holdredge C, Altieri AD (2009) Substrate mediates consumer control of salt marsh cordgrass on Cape Cod, New England. Ecology 90:2108-2117

Bortolus A, Iribarne O (1999) Effects of the SW Atlantic burrowing crab Chasmagnathus granulata on a Spartina salt marsh. Mar Ecol Prog Ser 178:79-88

Bortolus A, Schwindt E, Iribarne O (2002) Positive plantanimal interactions in the high marsh of an Argentinean coastal lagoon. Ecology 83:733-742

Botto F, Iribarne O (2000) Contrasting effects of two burrowing crabs (Chasmagnathus granulata and Uca uruguayensis) on sediment composition and transport in estuarine environments. Estuar Coast Shelf Sci 51:141-151

$>$ Botto F, Valiela I, Iribarne O, Marinetto P, Alberti J (2005) Impact of burrowing crabs on $\mathrm{C}$ and $\mathrm{N}$ sources, control, and transformations in sediments and food webs of SW Atlantic estuaries. Mar Ecol Prog Ser 293:155-164

Chapman VJ (1960) Salt marshes and salt deserts of the world. Hill, London

> Colby DR, Fonseca MS (1984) Population dynamics, spatial dispersion and somatic growth of the sand fiddler crab Uca pugilator. Mar Ecol Prog Ser 16:269-279

> Craft CB (1996) Dynamics of nitrogen and phosphorus retention during wetland ecosystem succession. Wetl Ecol Manag 4:177-187

Craft CB, Seneca ED, Broome SW (1991) Porewater chemistry of natural and created marsh soils. J Exp Mar Biol Ecol 152:187-200

Craft CB, Reader J, Sacco JN, Broome SW (1999) Twenty-five years of ecosystem development of constructed Spartina alterniflora (Loisel) marshes. Ecol Appl 9:1405-1419

$>$ Daleo P, Fanjul E, Casariego AM, Silliman BR, Bertness MD, Iribarne O (2007) Ecosystem engineers activate mycorrhizal mutualism in salt marshes. Ecol Lett 10:902-908

Ellison AM, Farnsworth EJ, Twilley RR (1996) Facultative mutualism between red mangroves and root-fouling sponges in Belizean mangal. Ecology 77:2431-2444

Fanjul E, Grela MA, Iribarne O (2007) Effects of the dominant SW Atlantic intertidal burrowing crab Chasmagnathus granulatus on sediment chemistry and nutrient distribution. Mar Ecol Prog Ser 341:177-190

Fanjul E, Grela MA, Canepuccia A, Iribarne O (2008) The Southwest Atlantic burrowing crab Neohelice granulata modifies nutrient loads of phreatic waters entering coastal area. Estuar Coast Shelf Sci 79:300-306

FitzGerald DM, Fenster MS, Argow BA, Buynevich IV (2008) Coastal impacts due to sea-level rise. Annu Rev Earth Planet Sci 36:601-647

Frey RW, Basan PB (1985) Coastal sedimentary environments. In: Davis RA (ed) Coastal salt marshes. Springer-Link, New York, NY, p 225-301

Hoffman JA, Katz J, Bertness MD (1984) Fiddler crab depositfeeding and meiofaunal abundance in salt marsh habitats. J Exp Mar Biol Ecol 82:161-174

Howes BL, Howarth RW, Teal JM, Valiela I (1981) Oxidationreduction potentials in a salt marsh: spatial patterns and interactions with primary production. Limnol Oceanogr 26:350-360
Jones CG, Lawton JH, Shachak M (1994) Organisms as ecosystem engineers. Oikos 69:373-386

Kristensen E (2008) Mangrove crabs as ecosystem engineers; with emphasis on sediment processes. J Sea Res 59:30-43

> Levine JM, Brewer JS, Bertness MD (1998) Nutrients, competition and plant zonation in a New England salt marsh. J Ecol 86:285-292

Mendelssohn IA, Morris JT (2000) Eco-physiological controls on the productivity of Spartina alterniflora Loisel. In: Weinstein NP, Kreeger DA (eds) Concepts and controversies in tidal marsh ecology. Kluwer Academic Publishers, Dordrecht, p 59-80

> Mendelssohn IA, Seneca ED (1980) The influence of soil drainage on the growth of salt-marsh cordgrass Spartina alterniflora in North Carolina. Estuar Coast Mar Sci 11: $27-40$

Montague CL (1980) A natural history of temperate western Atlantic fiddler crabs (genus $U_{c a}$ ) with reference to their impact on the salt marsh. Contrib Mar Sci 23:25-55

Morris JT, Sundareshwar PV, Nietch CT, Kjerfve B, Cahoon DR (2002) Responses of coastal wetlands to rising sea levels. Ecology 83:2869-2877

Nobbs M, McGuiness KA (1999) Developing methods for quantifying the apparent abundance of fiddler crabs (Ocypodidae: Uca) in mangrove habitats. Aust J Ecol 24:43-49

Odum EP (1969) The strategy of ecosystem development. Science 164:262-270

- Osgood DT, Zieman JC (1993) Spatial and temporal patterns of substrate physiochemical parameters in different-aged barrier island marshes. Estuar Coast Shelf Sci 37:421-436

> Peterson BJ, Heck KL (1999) The potential for suspension feeding bivalves to increase seagrass productivity. J Exp Mar Biol Ecol 240:37-52

> Pruell RJ, Taplin BK, Lake JL, Jayaraman S (2006) Nitrogen isotope ratios in estuarine biota collected along a nutrient gradient in Narragansett Bay, Rhode Island, USA. Mar Pollut Bull 52:612-620

Redfield AC (1972) Development of a New England salt marsh. Ecol Monogr 42:201-237

> Redfield AC, Rubin M (1962) The age of salt marsh peat and its relation to recent changes in sea level at Barnstable, Massachusetts. Proc Natl Acad Sci USA 48: $1728-1735$

Regnault M (1987) Nitrogen excretion in marine and freshwater Crustacea. Biol Rev Camb Philos Soc 62:1-24

> Teal JM (1958) Distribution of fiddler crabs in Georgia salt marshes. Ecology 39:185-193

> Teal JM (1962) Energy flow in the salt marsh ecosystem of Georgia. Ecology 43:614-624

> Thompson SP, Paerl HW, Go MC (1995) Seasonal patterns of nitrification and denitrification in a natural and restored salt marsh. Estuaries 18:399-408

Tuerk KJS, Aelion CM (2005) Microbial nitrogen removal in a developing suburban estuary along the South Carolina coast. Estuaries 28:364-372

Tyler AC, Zieman JC (1999) Patterns of development in the creekbank region of a barrier island Spartina alterniflora marsh. Mar Ecol Prog Ser 180:161-177

Tyler AC, Mastronicola TA, McGlathery KJ (2003) Nitrogen fixation and nitrogen limitation of primary production along a natural marsh chronosequence. Oecologia 136: 431-438

Valiela I, Teal JM (1974) Nitrogen limitation of salt-marsh vegetation. In: Reimold RJ, Queen WH (eds) Ecology of halophytes. Academic Press, New York, NY, p 547-563

> Valiela I, Teal JM (1979) Nitrogen budget of a salt-marsh ecosystem. Nature 280:652-656 